\title{
Variation of density and flash point in acid degummed waste cooking oil
}

\section{Gina Vlahopoulou' | Giacomo Luigi Petretto' Carlo Piga' I Alberto Mannu}

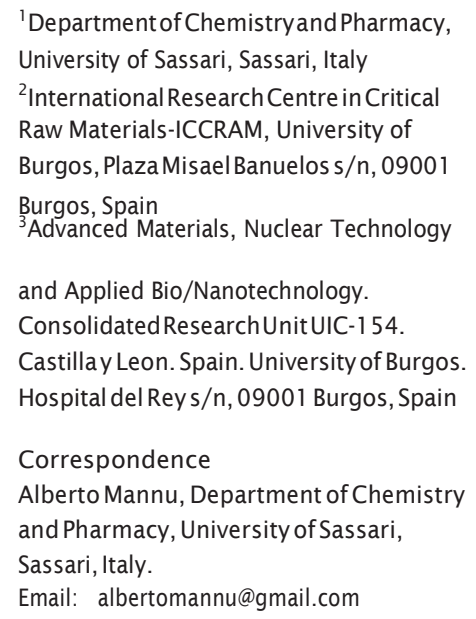

'Department of ChemistryandPharmacy, University of Sassari, Sassari, Italy ${ }^{2}$ International Research Centre in Critical Raw Materials-ICCRAM, University of Burgos, Plaza Misael Banuelos s/n, 09001 Burgos, Spain ${ }^{3}$ Advanced Materials, Nuclear Technology and Applied Bio/Nanotechnology. Consolidated ResearchUnit UIC-154. Castillay Leon. Spain. University of Burgos. Hospital del Reys/n, 09001 Burgos, Spain

\section{Correspondence}

Alberto Mannu, Department of Chemistry and Pharmacy, University of Sassari, Sassari, Italy.

Email: albertomannu@gmail.com

\begin{abstract}
Recycling of waste cooking oil represents a source of convenie, the large number of products derived from the treatment of $w$ usually of acid or basic degumming followed by a filtration ster. The effect of the specific type of acid degumming on the density and on the flash point of the rec/cled oil was evaluated employing full factorial design. Two mathematical equations were derived which allow to estimate respectively the density and the flash point of the recycled oil, depending on the: (a) pH of the washing solution, (b) oil/water ratio, (c) temperature of the system, and (d) the stirring time.

\section{Practical applications}

Recycle of waste cooking oil presents several advantages. Mainly it is beneficial for the environment and considered as mandatory by law in several countries, and could furnish a useful low price raw material for several kind of industries. Recently, a multitude of local small scale industries have based their business on this topic and the recycling process employed often consists in a degumming step followed by filtration. This article deals with the tuning of the main parameters of the degumming step related with the density and the flash point of the final product. These parameters are important especially for lubricant synthesis.
\end{abstract}

\section{I INTRODUCTION}

Worldwide, consumption of vegetable oils has constantly grown in the last 20 years and its current global market can be estimated in about 160 million tonnes peryear(Linet al., 2013).

Most of the produced vegetable oil is used directly as food ingredient ( $80 \%$ of the total production) and as cooking oil generating a large quantity of wastes.

In the last years, the transformation of vegetable oils in chemical feedstock has attracted a lot of attentions with the aim to replace synthetic mixture derived from petroleum, much more impacting on the environment and, in general, on public health (Boyde, 2002; Rac \& Vencl, 2012; Singhabhandhu \& Tezuka, 2010a).

Recycling waste cooking oils allows to provide biodegradable, nontoxic, and green feedstocks to the industry of vegetable oil derivatives, which ranges from energy (direct burning, Singhabhandhu \& Tezuka, 2010b) or bio-diesel (No, 2011; Talebian-Kiakalaieh, Amin, \& Mazaheri, $2013)$ to raw material, bio-lubricant (Petran, Pedisic, Orlovic, Podolski,
\& Bradac, 2008; Shashidhara \&Jayaram, 2010) and fermentation media 43 to soap industry (Panadare \& Rathod, 2015).

Additionally, considering the economical aspect, the exploita- 45 tion of waste cooking oil instead of pure vegetal oil represents the 46 cheaper solution for industry. The waste cooking oil has been sold 47 for decades as animal feed until its unconditional banning emitted 48 by the European Commission, in 2002, due to the great number of 49 potentially harmful compounds generated during frying which could 50 migrate in food chain by contamination of animal meat (Cvengros \& 51 Cvengrosova, 2004). Furthermore, storage and disposal of waste 52 cooking oil may contaminate environmental water requiring specific 53 and expensive methods. 54

The choice of the recycling process of waste cooking oils depends 55 on the field of application of the final product but usually consists of 56 the following three main steps: degumming, distillation or filtration, and 57 clarification. Sometimes, as in the case of crude vegetal oils, the 58 degumming process can be included in the filtration step (Haas, 2005; 59 Koris \& Vatai, 2002; Tiwari, Kumar, \& Raheman, 2007). 
2of 6l WI LEY $\begin{aligned} & \text { Journal of } \\ & \text { Food Processing and Preservation }\end{aligned}$ 77 2004).

During the degumming step, the amount of phospholipids, free fatty acids, waxes, metal ions, and coloring pigments present in the waste oil in large amount as consequence of the process of frying is drastically reduced (De Moura, Goncalves, Cunha Petrus, \& Viotto, 2005; Ochoa, Pagliero, Marchese, \& Mattea, 2001). The standard degumming treatment is usually performed by acidic, neutral, or basic water treatment, ultrafiltration, or enzymatic treatment (Boyde, 2002; Sampaio et al., 2015; Yang, Wang, Yang, Mainda, \&Guo, 2006).

Local recycling of waste cooking oil for application different from bio-diesel can be a rentable business for small industries, in particular in the field of bio-lubricants (Fox \& Stachowiak, 2007; Vintila, 2009). As confirmation of this growing interest, a large number of small-scale apparatuses forvegetableoil recycling are currentlyavailable on the market.

The common recycle processes available with most of the commercial apparatuses consist in a filtration under vacuum, sometimes followed by a clarification step (Pohler, Modler, Bruhnkeh, \& Hidenberg,

Supercritical $\mathrm{CO}_{2}$ extraction represents an alternative process, already applied to olive oil purification (Sesti Oss'®a, Caputoa, Graciab, \& Reverchona, 2004)

Little attention has been dedicated to the degumming step of waste cooking oil for small-scale application as recycling in small areas where the transport of the waste cooking oil to the industrial plant represents an important cost of the overall process.

In order to shed some light on the usefulness of the specific water degumming of waste cooking oils, a systematic study of the influence of the main parameters of water degumming of waste cooking oils on the density and on the flash point of the final product has been conducted.

\section{I MATERIALS AND METHODS}

\section{1 | Waste oil samples}

Waste cooking oil samples were collected from domestic supplier in the geographic area of north Sardinia. Sulfuric acid $99.999 \%$ was purchased from Sigma Aldrich. Deionized Water was used for all the experiments.

\section{2 | General degumming procedure}

The selected quantity of waste cooking oil was mixed to the opportune amount of water in a round bottom flask, and the mixture was stirred for the indicated time (Tables 1 and 4). Then, the mixture was transferred in a separatory funnel and decanted for $2 \mathrm{hr}$. The organic layerwas then collectedand stored in the darkatroomtemperatureuntilanalysis.

\section{3 | Determination of density}

The density, defined as "the mass of liquid per unit volume at $158 \mathrm{C}$ with the standard unit of measurement being kilograms per cubic metre," was determined according standard method ASTM 1298-12b (ASTM 1298, 2012) with minor modification. Briefly, $15 \mathrm{~g}$ of degummed oil were transferred in a hydrometer cylinder. The sample was homogenized by stirring with a glass rod. The densimeter was then lowered into the test portion and allowed to settle until the tempera- 108 ture equilibrium has been reached.

\section{4 | Determination of flash point}

The flash point, defined as "the lowest temperature at which applica- 111 tion of an ignition source causes the vapours of a specimen of the sam- 112 ple to ignite under specified conditions of test," of the degummed oil 113 was determined with a Pensky-Martens-SDM 750/E instrument 114 according to standard method ASTM D93-13 (ASTM D93-13e1, 2013) 115 with minor modifications. Briefly, $10 \mathrm{~g}$ of degummed oil were heated at 116 constant rate of $5 \mathrm{8} C / \mathrm{min}$. A natural gas flame was directed toward the 117 oil sample at constant intervals of $10 \mathrm{~s}$ until a flame occurred over the 118 entire surface of the sample.

\section{5 | Experimental design}

A multivariate methodology was applied in order to optimize the inde- 121 pendent variables $(k)$ oil $/ \mathrm{H}_{2} \mathrm{O}$ ratio $\mathrm{pH}$, temperature, and stirring time. 122 Full factorial design ( $n^{k} 516$ experiments) (Box, Stuart-Hunter, Hunter, 123 Stuart-Hunter, \& Hunter, 2005) model was employed to study the 124 response density and flash point of the degummed oils. 21 and 11125 denoted the low and high levels ( $n$ ) of the independent variables, 126 respectively. The Statgraphics Centurion v 15.1.02 software was used 127 for the experimental design data analysis and constructs the response 128 surface.

\section{6 | Statistical analysis}

All experiments were conducted in triplicate. All statistical analyses 131 were performed comparing data with unpaired Student's $t$-test. When 132 the data followed a normal distribution, the sample was evaluated by 133 the Kolmogorov-Smirnov and Shapiro tests. A $p<.05$ was considered 134 statistically significant.

\section{3 | RESULTS AND} Sixteen waste cooking oils from $d$ north of Sardinia (Italy) were subn Sigma Aldrich Italy consideration the following parain oil/water ratio, temperature of the

Since the studied variables ar! the optimization approach would at time. Then, to optimize the number of experiments and to screen the interaction of all the variables considered, experimental design (DOE) was employed.

Sixteen experiments were obtar combining two levels ( $n$ ) and four independent factors (k): pH, oil/ $\mathrm{H}_{2} \mathrm{O} 147$ ratio, temperature, and stirring time. The combination of the four inde- 148 pendent variables considered allows evaluating their effect on the den- 149 sity and the flash point of the recycled oil.

For every output (density and flash point), a mathematical equation 151 describing the correlation of the four factors considered has been 152 derived as reported in the next section. 
VLAHOPOULOU ET AL.

Journal of

Food Processing and Preservation

Institute of
Food Science
+Technology

WILEY $\stackrel{3 \text { of } 6}{ }$

TABLE 1 Density measured ( $\mathrm{g} / \mathrm{L}$ ) for every experiment conducted

\begin{tabular}{|llllll} 
Experiment & $\mathrm{pH}$ & $\begin{array}{l}\mathrm{Oil} / \mathrm{H}_{2} \mathrm{O} \\
\text { ratio }(\%)\end{array}$ & $\begin{array}{l}\text { Temperature } \\
(8 \mathrm{C})\end{array}$ & $\begin{array}{l}\text { Time } \\
(\mathrm{hr})\end{array}$ & $\begin{array}{l}\text { Density } \\
(\mathrm{g} / \mathrm{L})\end{array}$ \\
\hline 1 & 4.0 & 30.0 & 20.0 & 5.0 & 0.910 \\
\hline 2 & 4.0 & 30.0 & 20.0 & 24.0 & 0.948 \\
\hline 3 & 6.0 & 60.0 & 20.0 & 5.0 & 0.924 \\
\hline 4 & 4.0 & 60.0 & 20.0 & 5.0 & 0.926 \\
\hline 5 & 4.0 & 60.0 & 20.0 & 24.0 & 0.922 \\
\hline 6 & 4.0 & 30.0 & 60.0 & 24.0 & 0.920 \\
\hline 7 & 6.0 & 60.0 & 60.0 & 24.0 & 0.928 \\
\hline 8 & 6.0 & 30.0 & 20.0 & 5.0 & 0.932 \\
\hline 9 & 4.0 & 60.0 & 60.0 & 5.0 & 0.922 \\
\hline 10 & 6.0 & 60.0 & 20.0 & 24.0 & 0.920 \\
\hline 11 & 4.0 & 60.0 & 60.0 & 24.0 & 0.926 \\
\hline 12 & 6.0 & 30.0 & 20.0 & 24.0 & 0.974 \\
\hline 13 & 6.0 & 60.0 & 60.0 & 5.0 & 0.926 \\
\hline 14 & 4.0 & 30.0 & 60.0 & 5.0 & 0.924 \\
\hline 15 & 6.0 & 30.0 & 60.0 & 5.0 & 0.922 \\
\hline 16 & 6.0 & 30.0 & 60.0 & 24.0 & 0.930 \\
\hline
\end{tabular}

1543.1 | Effect of pH, oil/ $\mathrm{H}_{2} \mathrm{O}$ ratio, temperature, and

155 stirring time on density

156 For every experiment, the density value was determined in agreement

157 with the standard method ASTM 1298-12b (ASTM 1298, 2012) at T1 $158228 \mathrm{C}$; the results are reported in Table 1.

159 The effect of the factors considered on the density and their interT2 160 action was determined according to Box et al. (2005) (Table 2).

All the parameters are comparable, indicatinganabsence of a prebetween the values confirms this conclusion. The analysis of the

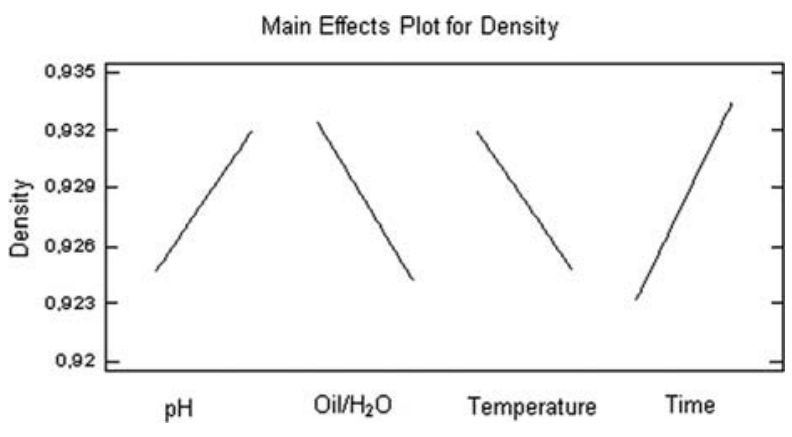

FIGURE 1 Medium effect of the passage of the levels from 21 to 11 for every single parameter

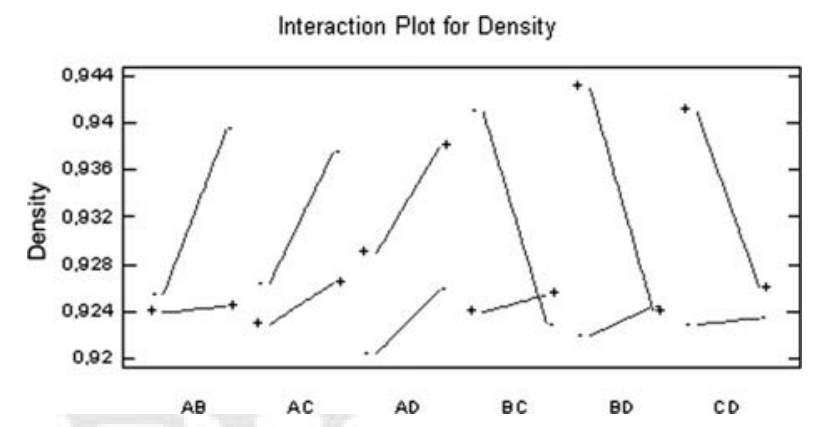

FIGURE 2 Graphic representation of the interaction of the parameters on density. A $5 \mathrm{pH}, \mathrm{B} 5$ oil/ $\mathrm{H}_{2} \mathrm{O}$ ratio, C 5 temperature, $\mathrm{D} 5$ stirring time
TABLE 2 Effect of the factors on density

\begin{tabular}{|c|c|c|c|c|c|c|c|c|}
\hline Effect & Value & Standard error & p Value & 5 & 0.922 & 0.923625 & 0.898564 & 0.948686 \\
\hline Average & 0.92837 & 0.00293949 & - & 6 & 0.920 & 0.924625 & 0.899564 & 0.949686 \\
\hline $\mathrm{pH}$ & 0.00725 & 0.00587899 & .2723 & 7 & 0.928 & 0.920625 & 0.895564 & 0.945686 \\
\hline$\%$ of $\mathrm{H}_{2} \mathrm{O}$ & 20.00825 & 0.00587899 & .2195 & 8 & 0.932 & 0.934625 & 0.909564 & 0.959686 \\
\hline Temperature & 20.00725 & 0.00587899 & .2723 & 9 & 0.922 & 0.932125 & 0.907064 & 0.957186 \\
\hline Time & 0.01025 & 0.00587899 & .1417 & 10 & 0.920 & 0.929625 & 0.904564 & 0.954686 \\
\hline $\mathrm{pH} 3 \%: \mathrm{H}_{2} \mathrm{O}$ & 20.00675 & 0.00587899 & .3029 & 11 & 0.926 & 0.922125 & 0.897064 & 0.947186 \\
\hline pH3temperature & 20.00375 & 0.00587899 & .5516 & 12 & 0.974 & 0.965125 & 0.940064 & 0.990186 \\
\hline $\mathrm{pH} 3$ time & 0.00175 & 0.00587899 & .7779 & 13 & 0.926 & 0.927125 & 0.902064 & 0.952186 \\
\hline \%: $\mathrm{H}_{2} \mathrm{O} 3$ temperature & 0.00975 & 0.00587899 & .1581 & 14 & 0.924 & 0.913125 & 0.888064 & 0.938186 \\
\hline$\%: \mathrm{H}_{2} \mathrm{O} 3$ time & 20.01075 & 0.00587899 & .1270 & 15 & 0.922 & 0.921625 & 0.896564 & 0.946686 \\
\hline Time 3 temperature & 20.00775 & 0.00587899 & .2446 & 16 & 0.930 & 0.936625 & 0.911564 & 0.961686 \\
\hline
\end{tabular}

TABLE 3 Density values calculated with the theoretical model developed

\begin{tabular}{|lllll} 
Experiment & $\begin{array}{l}\text { Observed } \\
\text { Value }\end{array}$ & $\begin{array}{l}\text { Calculated } \\
\text { Value }\end{array}$ & $\begin{array}{l}\text { Lower } \\
\text { LC95.0\% }\end{array}$ & $\begin{array}{l}\text { Upper } \\
\text { LC95.0\% }\end{array}$ \\
\hline 1 & 0.910 & 0.918625 & 0.893564 & 0.943686 \\
2 & 0.948 & 0.945625 & 0.920564 & 0.970686 \\
\hline
\end{tabular}

3

$\begin{array}{lllll}0.924 & 0.920625 & 0.895564 & 0.945686\end{array}$

$\begin{array}{lllll}0.926 & 0.918125 & 0.893064 & 0.943186\end{array}$

$\begin{array}{llll}0.922 & 0.923625 & 0.898564 & 0.948686\end{array}$

$\begin{array}{llll}0.928 & 0.920625 & 0.895564 & 0.945686\end{array}$ 
J_ID: Customer A_ID: JFPP13533Ｃadmus Art: JFPP13533Ｅd. Ref. No.: JFPP-08-17-0891.R1Ｄate: 13-October-17

\section{4of 61 WI LEY $\begin{aligned} & \text { Journal of } \\ & \text { Food Processing and Preservation }\end{aligned}$}

164 variance (ANOVA) shows that no significant effect can be attributed to F1 165 anyofthe parameters considered $(p<.05)$ (Figure 1 ).

166 The lack of a significant effect of the interaction between the F2 167 parameters is reported in Figure 2.

168 A mathematical representation of the model obtained has been

169 implemented:

Density50:85216410:01616453pH

10:000746933oil3 $\mathrm{H}_{2} \quad$ O20:0001480263temperature 10:0025921 13time20:0002253pH3oil3 $\mathrm{H}_{2} \mathrm{O}$ 20:000093753pH3temperature10:00009210533pH 3time10:000016253oil3 $\mathrm{H}_{2}$ O3temperature 20:00003771 933oil3 $\mathrm{H}_{2}$ O3time 20:00002039473temperature3time:

All the values calculated with the mathematical model developed lay inside the confidence limit (LC) of 95\% with respect to the observed

T3 172 values indicating the goodness of the model (Table 3 ).

TABLE 4 Prevision of the best experimental conditions for minimum and maximum density

\begin{tabular}{lcc}
\hline Parameter & Minimum (0.913) & Maximum (0.965) \\
\hline $\mathrm{pH}$ & 4.0 & 6.0 \\
\hline Oil/ $\mathrm{H}_{2} \mathrm{O}$ ratio & 30.0 & 30.0 \\
\hline Temperature & 60.0 & 20.0 \\
Time & 5.0 & 24.0 \\
\hline
\end{tabular}

TABLE 5 Flash point values $(8 \mathrm{C})$

\begin{tabular}{|llllrl} 
Entry & $\mathrm{pH}$ & $\begin{array}{l}\text { Oil/ } \mathrm{H}_{2} \mathrm{O} \\
(\%) \text { ratio }\end{array}$ & $\begin{array}{l}\text { Temperature } \\
(8 \mathrm{C})\end{array}$ & $\begin{array}{l}\text { Time } \\
(\mathrm{hr})\end{array}$ & $\begin{array}{l}\text { Flash } \\
\text { point }(8 \mathrm{C})\end{array}$ \\
\hline 1 & 4.0 & 30.0 & 20.0 & 5.0 & 270 \\
\hline 2 & 4.0 & 30.0 & 20.0 & 24.0 & n.d. \\
\hline 3 & 6.0 & 60.0 & 20.0 & 5.0 & 274 \\
\hline 4 & 4.0 & 60.0 & 20.0 & 5.0 & 276 \\
\hline 5 & 4.0 & 60.0 & 20.0 & 24.0 & 272 \\
\hline 6 & 4.0 & 30.0 & 60.0 & 24.0 & 278 \\
\hline 7 & 6.0 & 60.0 & 60.0 & 24.0 & 284 \\
\hline 8 & 6.0 & 30.0 & 20.0 & 5.0 & 284 \\
\hline 9 & 4.0 & 60.0 & 60.0 & 5.0 & 276 \\
\hline 10 & 6.0 & 60.0 & 20.0 & 24.0 & 284 \\
\hline 11 & 4.0 & 60.0 & 60.0 & 24.0 & 286 \\
\hline 12 & 6.0 & 30.0 & 20.0 & 24.0 & 280 \\
\hline 13 & 6.0 & 60.0 & 60.0 & 5.0 & 278 \\
\hline 14 & 4.0 & 30.0 & 60.0 & 5.0 & 286 \\
\hline 15 & 6.0 & 30.0 & 60.0 & 5.0 & 290 \\
\hline 16 & 6.0 & 30.0 & 60.0 & 24.0 & 284 \\
\hline
\end{tabular}

n.d., not determined.
The density in the degummed oil ranges from a minimum value of 173 $0.913 \mathrm{~g} / \mathrm{L}$ to a maximum value of $0.965 \mathrm{~g} / \mathrm{L}$, and it can be reached 174 working at the following conditions (Table 4).

\subsection{Effect of $\mathrm{pH}$, oil/ $\mathrm{H}_{2}$ Oratio, temperature, and $\quad 176$} stirring time on flash point

The flash point has been determined in agreement with standard 178 method ASTM D93-13 (ASTM D93-13e1, 2013), the result for every 179 experiment is reported in Table 5.

The effect of the factors on the flash point and their interaction 181 has been determined in agreement to Box et al. (2005); the results are 182 reported in Table 6.

The values referred to the effects of $\mathrm{pH}$ and temperature, which 184 are significantly bigger than all the others. As regard of the interaction 185 of the factors, the percentage of $\mathrm{H}_{2} \mathrm{O} 3$ time shows a $p$-value of $<.05186$ indicating that the passage from levels 21 to 11 has an influence on 187 the flash point with a probability higher than $95 \%$. The positive value 188 referred to this interaction means an incremental contribute of all the 189 three factors on flash point (Figure 3).

The lines obtained in Figure 3 represent the medium effect of the 191 passage from levels 21 to 11 , and as expected for the factors $\mathrm{pH}$ and 192

TABLE 6 Effect of the factors on the flash point and statistic inference

\begin{tabular}{lrll} 
Effect & Value & Standard error & p Value \\
\hline Average & 279.0 & 1.06066 & \multicolumn{1}{l}{-} \\
\hline $\mathrm{pH}$ & 6.5 & 2.12132 & .0375 \\
\hline$\% \mathrm{H}_{2} \mathrm{O}$ & 20.5 & 2.12132 & .8252 \\
\hline Temperature & 7.5 & 2.12132 & .0241 \\
\hline Time & 20.5 & 2.12132 & .8252 \\
\hline $\mathrm{pH} 3 \%: \mathrm{H}_{2} \mathrm{O}$ & 24.0 & 2.12132 & .1324 \\
\hline $\mathrm{pH} 3$ temperature & 24.0 & 2.12132 & .1324 \\
\hline $\mathrm{pH} 3$ time & 2.0 & 2.12132 & .3992 \\
\hline \%: $\mathrm{H}_{2} \mathrm{O} 3$ temperature & 23.0 & 2.12132 & .2302 \\
\hline \%: $\mathrm{H}_{2} \mathrm{O} 3$ time & 6.0 & 2.12132 & .0474 \\
\hline Time 3 temperature & 1.0 & 2.12132 & .6619
\end{tabular}

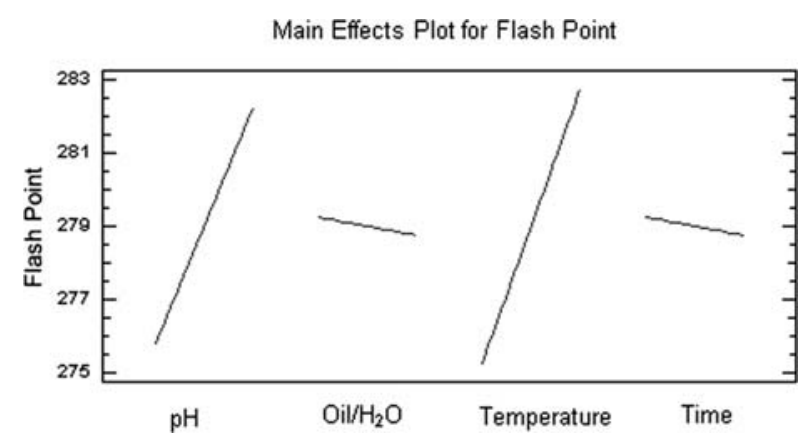

FIGURE 3 Graphic representation of the effect of the factors on flash point 
Interaction Plot for Flash Point

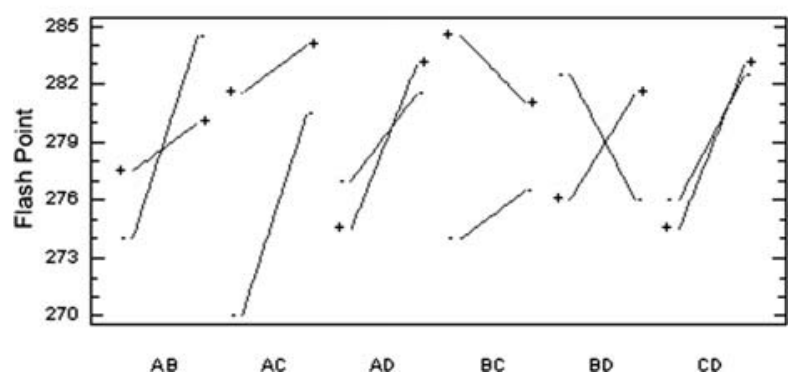

FIGURE 4 Graphic representation of the interactions between the factors on flash point. A $5 \mathrm{pH}, \mathrm{B} 5 \mathrm{oil} / \mathrm{H}_{2} \mathrm{O}$ ratio, C 5 temperature, D 5 stirring time

TABLE 7 Estimatedvalues of flash point

\begin{tabular}{|lllll} 
Entry & $\begin{array}{l}\text { Observed } \\
\text { value }\end{array}$ & $\begin{array}{l}\text { Calculated } \\
\text { value }\end{array}$ & $\begin{array}{l}\text { Lower LC } \\
95.0 \%\end{array}$ & $\begin{array}{l}\text { Upper LC } \\
95.0 \%\end{array}$ \\
\hline 1 & 270.0 & 271.5 & 261.882 & 281.118 \\
\hline 2 & n.d. & 262.0 & 246.05 & 277.95 \\
\hline 3 & 274.0 & 276.5 & 267.503 & 285.497 \\
\hline 4 & 276.0 & 272.0 & 263.003 & 280.997 \\
\hline 5 & 272.0 & 274.5 & 264.882 & 284.118 \\
\hline 6 & 278.0 & 277.5 & 267.882 & 287.118 \\
\hline 7 & 284.0 & 284.5 & 275.503 & 293.497 \\
\hline 8 & 284.0 & 284.0 & 275.003 & 292.997 \\
\hline 9 & 276.0 & 279.5 & 270.503 & 288.497 \\
\hline 10 & 284.0 & 283.0 & 274.003 & 291.997 \\
\hline 11 & 286.0 & 284.0 & 275.003 & 292.997 \\
\hline 12 & 280.0 & 278.5 & 268.882 & 288.118 \\
\hline 13 & 278.0 & 276.0 & 266.382 & 285.618 \\
\hline 14 & 286.0 & 285.0 & 276.003 & 293.997 \\
\hline 15 & 290.0 & 289.5 & 280.503 & 298.497 \\
\hline 16 & 284.0 & 286.0 & 277.003 & 294.997 \\
\hline
\end{tabular}

n.d., not determined.

TABLE 8 Experimental conditions corresponding to the maximum and the minimum flash point value

\begin{tabular}{lll} 
Factor & Minimum $\left(262.9{ }_{8} \mathrm{C}\right)$ & Maximum $\left(289.5{ }_{8} \mathrm{C}\right)$ \\
\hline $\mathrm{pH}$ & 4.0 & 6.0 \\
\hline Oil/ $\mathrm{H}_{2} \mathrm{O}$ & 30.0 & 30.0 \\
\hline Temperature & 22.4 & 60.0 \\
Time & 23.9 & 5.0 \\
\hline
\end{tabular}

temperature, they have a positive slope, higher in value with respect to the lines referred to the other factors

F4 195

In the case of the interactions (Figure 4), the combination of BD

196 corresponding to the variables $\% \mathrm{H}_{2} \mathrm{O}$-time shows an antiparallel trend. The regression coefficients are reported in the following 197 equation:

Flash point5220:276111:72373pH10:5447373oil3 $\mathrm{H}_{2} \mathrm{O}$
1 0:8743423temperature21:605263time
20:1333333pH3Oil= $\mathrm{H}_{2} \mathrm{O} 20: 13 \mathrm{pH} 3$ temperature
10:1052633pH3Time20:0053oil3 $\mathrm{H}_{2}$ O3temperature
10:02105263Oil3 $\mathrm{H}_{2}$ O3time
10:002631583temperature3time

All the values obtained using the model lay in the interval deter- 199 mined from the confidence limits of 95\% with respect to the observed 200 dataas confirmation of the goodness of the model (Table 7).

The flash point after degumming ranges within the minimum value 202 of $262.98 \mathrm{C}$ and the maximum value of $289.58 \mathrm{C}$ and the corresponding 203 operating conditions are reported in Table 8.

\section{4 | CONCLUSIONS}

Through experimental full factorial design $2^{4}$, the effects of $\mathrm{pH}$, per- 206 centage of $\mathrm{H}_{2} \mathrm{O}$, temperature and time during water degumming of 207 waste cooking oil on the density, and the flash point of the final prod- 208 ucthave been studied.

None of the factors considered affect significantly the density in 210 the passage from level 21 to level 11 .

In contrast, the flash point is significantly influenced from $\mathrm{pH}$, tem- 212 perature, and the interaction between factors such as percentage of 213 $\mathrm{H}_{2} \mathrm{O}$ and time.

Two mathematical models based on experimental data have been 215 implemented for estimate the best operative conditions in water 216 degumming of waste cooking oils in order to tune the density and the 217 flash point of the recycled oil.

Determination of analogues models for other characteristic param- 219 eters of waste cooking oil are currently subject of research.

\section{ACKNOWLEDGMENT}

The authors thank Sardegna Ricerche and the regional programme 222 INSIGHT for the support in the developing of the business idea.

ORCID

Alberto Mannu (iD) http://orcid.org/0000-0001-7623-7475

\section{REFERENCES}

ASTM D1298-12b. (2012). Standard test method for density, relative density, 227 or API gravity of crude petroleum and liquid petroleum products by hydrome- 228 ter method. West Conshohocken, PA: ASTM International, www.astm.org. 229

ASTM D93-13e1. (2013). Standard_test methods for flash_point by Pensk Martens closed cup tester. West ${ }_{1}^{1}$ Alberto Mannu (albertomannu@gmail.com) tional, www.astm.org. 1 2017-10-13 16:24:17

Box, G. E. P., Stuart-Hunter, J., d experimenters: Design, innovatiol' Location is correct NJ, USA: Wiley.

Boyde, S. (2002). Green lubricantsi of lubrication. Green Chemistry, 
6of 6 1 W LEY $\begin{aligned} & \text { Journal of } \\ & \text { Food Processing and Preservation }\end{aligned}$

Cvengros, J., \& Cvengrosova, Z. (2004). Used Frying oil and fat and their utilization in the production of methyl esters of higher fatty acid. Biomass Bioenergy, 27, 173-181.

De Moura, J. M. L. N., Goncalves, L. A. G., Cunha Petrus, J. C., \& Viotto, L. A. (2005). Degumming of vegetable oil by microporous membrane. Journal of Food Engineering, 70, 473-478.

Fox, N. J., \& Stachowiak, G. W. (2007). Vegetable oil-based lubricants-A review of oxidation. Tribology International, 40, 1035-1046.

Haas, M.J. (2005). Improving the economics of biodiesel production through the use of low value lipids as feedstocks: Vegetable oil soapstock. Fuel Processing Technology, 86, 1087-1096.

Koris, A., \& Vatai, G. (2002). Dry degumming of vegetable oils by membrane filtration. Desalination, 148, 149-153.

Lin, C. S. K., Pfaltzgraff, L. A., Herrero-Davila, L., Mubofu, E. B., Abderrahim, S., Clark,J. H., ... Luque, R. (2013). Food waste as a valuable resource for the production of chemicals, materials and fuels. Current situation and global perspective. Energy \& Environmental Science, 6, 426-464.

No, S. Y. (2011). Inedible vegetable oils and their derivatives for alternative diesel fuels in $\mathrm{Cl}$ engines: A review. Renewable and Sustainable Energy Reviews, 15, 131-149.

Ochoa, N., Pagliero, C., Marchese, J., \& Mattea, M. (2001). Ultrafiltration of vegetable oils: Degumming by polymeric membranes. Separation and Purification Technology, 22-23, 417-422.

Panadare, D. C., \& Rathod, V. K. (2015). Applications of waste cooking oil other than biodiesel: A review. Iranian Journal of Chemical Engineering, 12(3), 55-76.

Petran, J., Pedisic, L., Orlovic, M., Podolski, S, \& Bradac, V. (2008). Biolubricants from natural waste oils and fats. Goriva i Maziva, 47, 463-478.

Pohler, J., Modler, M., Bruhnkeh, D., \& Hidenberg, H. (2004). Method for reprocessing waste oils, base oils obtained according to said method and use thereof. US Patent No. 6,712, 954 B1.

Rac, A., \& Vencl, A. (2012). Ecological and technical aspects of the waste oils influence on environment. Tribology (1), ISSN 1221-4590.
Sampaio, K. A., Zyaykina, N., Wozniak, B., Tsukamoto, J., DE Greyt, W., 271 \& Stevens, C. V. (2015). Enzymatic degumming: Degumming effi- 272 ciency versus yield increase. European Journal of Lipid Science and 273 Technology, 117, 81-86.

Sesti Oss@a, L., Caputoa, G., Graciab, I., \& Reverchona, E. (2004). Con- 275 tinuous fractionation of used frying oil by supercritical $\mathrm{CO}_{2}$. Journal 276 of the American Oil Chemists' Society, 81, 879-885.

Shashidhara, Y. M., \& Jayaram, S. R. (2010). Vegetable oils as a potential 278 cutting fluid-An evolution. Tribology International, 43, 1073-1081. 279

Singhabhandhu, A., \& Tezuka, T. (2010a). The waste-to-energy frame- 280 work for integrated multi-waste utilization: Waste cooking oil, waste 281 lubricating oil, and waste plastics. Energy, 35, 2544-2551.

Singhabhandhu, A., \& Tezuka, T. (2010b). Prospective framework for col- 283 lection and exploitation of waste cooking oil as feedstock for energy 284 conversion. Energy, 35, 1839-1847.

Talebian-Kiakalaieh, A., Amin, N. A. S., \& Mazaheri, H. (2013). A review 286 on novel processes of biodiesel production from waste cooking oil. 287 Applied Energy, 104, 683-710.

Tiwari, A. L., Kumar, A., \& Raheman, H. (2007). Biodiesel production 289 from jatropha oil (Jatropha curcas) with high free fatty acids: An opti- 290 mized process. Biomass Bioenergy, 31, 569-575.

Vintila, I. (2009). The physical-chemical mechanism of the edible oils 292 deep refining. Scientific Study and Research, $X(2), 179-183$.

293

Yang, J. G., Wang, Y. H., Yang, B., Mainda, G., \& Guo, Y. (2006). Degum- 294

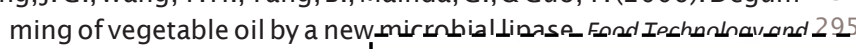
Biotechnology, 44(1), 101-104. | Alberto Mannu (albertomannu@gmail.com) I 2017-10-13 16:23:20 How to cite this article: Vlahol Page numbers are correct Piga C, Mannu A. Variation o' degummed waste cooking e13533. https://doi.org/10.1 1/ 1/jpp. 13533 